\title{
The Role of Cortical Na,K-ATPase in Distal Nephron Potassium Secretion by the Immature Canine Kidney
}

\author{
JOHN M. LORENZ, MARGERY A. MANULI, AND LYLE E. BROWNE \\ Department of Pediatrics, School of Medicine, State University of New York at Stony Brook, \\ Stony Brook, New York 11794-8111 J.M.L., L.E.B.] and Department of Biochemistry and Molecular Biophysics, \\ College of Physicians and Surgeons, Columbia University, New York, New York 10032 [M.A.M.]
}

\begin{abstract}
Amiloride-sensitive potassium secretion in response to acute potassium loading is lower in the newborn than in the adult. Potassium secretion is a function of late distal tubule and cortical collecting tubule $\mathrm{Na}, \mathrm{K}$-ATPase activity. Na,K-ATPase activity in vivo is determined by enzyme abundance and catalytic turnover. Chronic potassium supplementation increases potassium secretory capacity in the adult by increasing enzyme abundance in the late distal and cortical collecting tubules. We hypothesized that the lower potassium secretory capacity of the newborn was the result of lower late distal and cortical collecting tubule $\mathrm{Na}, \mathrm{K}-\mathrm{ATPase}$ activity and could be similarly enhanced. To test this hypothesis, newborn dogs were supplemented with $6 \mathrm{mmol} \mathrm{KCl} \cdot \mathrm{d}^{-1} \cdot \mathrm{kg}^{-1}$ for $1 \mathrm{wk}$; agematched litter mate controls were not ( $n=8$ pairs). Potassium supplementation resulted in a mean increase in $V_{\max }$ $\mathrm{Na}, \mathrm{K}$-ATPase activity in vitro (proportional to pump abundance) of $70 \pm 42 \%$. Mean Na,K-ATPase activities \pm SEM were $279 \pm 58$ versus $198 \pm 44 \mathrm{nmol}$ inorganic $P$. $\mathrm{h}^{-1} \cdot \mu \mathrm{gNA}^{-1}, p=0.05$. However, amiloride-sensitive potassium secretion after an acute potassium load of 20 $\mu \mathrm{mol} \cdot \mathrm{min}^{-1} \cdot \mathrm{kg}^{-1}$ over $150 \mathrm{~min}$ was not enhanced $(9.6 \pm$ 1.8 versus $8.9 \pm 0.8 \mu \mathrm{mol} \cdot \mathrm{min}^{-1} \cdot \mathrm{kg}^{-1}$, potassium-supplemented versus control animals). We conclude that lower enzyme abundance is not primarily responsible for the newborn's lower potassium secretory capacity. We speculate that the factor that limits secretion in the newborn during acute potassium loading does so by restricting catalytic turnover of the enzyme in vivo. (Pediatr Res 30 . $457-463,1991$ )
\end{abstract}

\section{Abbreviations}

$K_{1 / 2}$, substrate concentration at which the reaction velocity is half maximum

Na,K-ATPase, sodium-potassium-activated adenosine triphosphatase

$\mathrm{T}^{\mathrm{c}} \mathrm{H}_{2} \mathrm{O}$, free water reabsorption

TFK, tubular fluid potassium concentration

TTKG, transtubular potassium gradient

The potassium secretory response of the amiloride-sensitive segments of the immature nephron to acute potassium loading

Received April 12, 1990; accepted June 26, 1991

Correspondence: John M. Lorenz, M.D., Department of Pediatrics, School of Medicine, State University of New York at Stony Brook, Stony Brook, NY 11794 8111 .

Supported in part by a grant from The Children's Medical Research Foundation, Stony Brook, NY, and by USPHS Training Grant 5T32-DK07328. is less than that of the mature nephron (1). Transtubular potassium secretion in these nephron segments is driven by basolateral membrane $\mathrm{Na}, \mathrm{K}$-ATPase $(2,3)$. Na,K-ATPase activity has been shown to be lower in neonatal than adult nephron segments (46). It is possible, therefore, that the potassium secretory response of the immature nephron may be limited by lower $\mathrm{Na}, \mathrm{K}$-ATPase activity.

Results of a study that examined the effect of increasing $\mathrm{Na}, \mathrm{K}$ ATPase activity on the renal response to acute potassium loading in newborn dogs did not support this possibility (7). In that study, newborn dogs were subjected to chronic potassium supplementation for 1 to $3 \mathrm{wk}$ after birth to enhance Na,K-ATPase activity in potassium secretory nephron segment(s). Chronic potassium supplementation doubled $V_{\max }$ cortical $\mathrm{Na}, \mathrm{K}$-ATPase activity compared with controls (who received distilled water supplementation), but did not enhance urinary excretion of an acute potassium load in the newborn dog. These results were interpreted to indicate that $\mathrm{Na}, \mathrm{K}$-ATPase pump abundance is not rate limiting in excretion of a potassium load in the newborn. However, it is possible that water-loading the controls confounded the results by decreasing their cortical Na,K-ATPase activity or enhancing their renal response to acute potassium loading. Also, the design of that study did not allow potassium secretion to be estimated. Differences in potassium secretion may not be reflected in differences in potassium excretion $(8,9)$.

Therefore, the present study was undertaken to test the hypothesis that the lower potassium secretory capacity of the immature distal nephron during acute potassium loading is the result of lower $\mathrm{Na}, \mathrm{K}-\mathrm{ATPase}$ activity. In contrast to the previous study, controls received no supplementation of any kind. In addition, the pyrazine diuretic amiloride was infused after acute potassium loading so that potassium secretion could be estimated (1). The objectives of this study were to confirm that the results of the previous study could be reproduced, that water loading of the controls in the previous study did not account for those results, and that neither an increase in urinary potassium excretion nor an increase in tubular potassium secretion is associated with the enhanced $V_{\max }$ cortical $\mathrm{Na}, \mathrm{K}$-ATPase activity in the newborn dog.

\section{MATERIALS AND METHODS}

Studies were performed in newborn mongrel dogs. The protocol conformed to the NII Guide for the Care and Use of Laboratory Animals and was approved by the Laboratory Animal Users Committee of the State University of New York at Stony Brook.

Potassium supplementation. Sixteen newborn mongrel dogs were paired within litters and randomized to control or potassium-supplemented groups. Potassium-supplemented animals received $20 \mathrm{~mL} / \mathrm{kg}$ of $150 \mathrm{mM} \mathrm{KCl}$ solution twice daily by oral 
gavage for $1 \mathrm{wk}$ before acute potassium loading. This provided $6 \mathrm{mmol} \cdot \mathrm{d}^{-1} \cdot \mathrm{kg}^{-1}$ of supplemental potassium. This dose was extrapolated from that used in adult dogs by Berliner et al. (10). A gavage tube was passed twice daily in control animals, but no fluid was administered. All newborn dogs remained with and were suckled by their mother until the morning of the acute potassium loading experiment.

Potassium loading: amiloride blockade. After the 7-d supplementation period, control and potassium-supplemented animals from littermate pairs were removed from their mother on the same or alternate days to determine renal function under baseline conditions and in the potassium-loaded state without and then with blockade of distal nephron potassium secretion by amiloride.

Animals were anesthetized with $20-30 \mathrm{mg} / \mathrm{kg}$ of i.v. pentobarbital sodium. Rectal temperature was maintained at $37.9^{\circ} \mathrm{C}$ with a servo-controlled heat lamp and heated operating table. Animals were ventilated via a tracheostomy tube with a volume-controlled Harvard Rodent Ventilator (Harvard Apparatus Co. Inc., S. Natick, MA) and supplemental $\mathrm{O}_{2}$. Polyethylene catheters were placed in the left femoral vein for infusion of i.v. fluid and inulin, in each femoral artery for blood sampling and heart rate and blood pressure monitoring, and in each ureter for timed urine collections. All incisions were surgically closed.

After surgery, the ventilator was adjusted to maintain $\mathrm{PCO}_{2}$ at $35-45 \mathrm{~mm} \mathrm{Hg}(4.7-6.0 \mathrm{kPa})$. No further ventilator adjustments were subsequently made. A priming dose of $\left[{ }^{3} \mathrm{H}\right]$ inulin was given as a bolus followed by infusion of Isolyte $\mathrm{P}$ with $5 \%$ dextrose (Kendall-McGraw, Irvine, CA) and labeled inulin at a rate of 0.1 $\mathrm{mL} \cdot \mathrm{min}^{-1} \cdot \mathrm{kg}^{-1}$ as a maintenance solution. After a 1 -h recovery and equilibration period, a $60-\mathrm{min}$ baseline renal clearance was taken.

After this baseline clearance, an Isolyte $\mathrm{P} /$ inulin solution with $\mathrm{KCl}$ added to a final concentration of $200 \mathrm{mM}$ was substituted for the Isolyte $\mathrm{P} /$ inulin maintenance solution. This high potassium solution was infused continuously for $150 \mathrm{~min}$ at a rate of $0.1 \mathrm{~mL} \cdot \mathrm{min}^{-1} \cdot \mathrm{kg}^{-1}$ to provide $20 \mu \mathrm{mol} \mathrm{KCl} \cdot \mathrm{min}^{-1} \cdot \mathrm{kg}^{-1}$. All urine was collected during this infusion. After $120 \mathrm{~min}$ of $\mathrm{KCl}$ loading, a 30-min clearance was taken. Renal function during this second clearance period represents function in the potassium-loaded state in the presence of distal potassium secretion. At the end of this second clearance period, the high potassium infusion was discontinued, $1.0 \mathrm{mg}$ amiloride $/ \mathrm{kg}$ given over 5 to $10 \mathrm{~min}$, and Isolyte $\mathrm{P}$ with $5 \%$ dextrose solution with labeled inulin and amiloride infused at $0.1 \mathrm{~mL} \cdot \mathrm{min}^{-1} \cdot \mathrm{kg}^{-1}$ to provide $2.4 \mathrm{mg} \cdot \mathrm{h}^{-1} \cdot \mathrm{kg}^{-1}$ of amiloride continuously. This resulted in a potassium infusion rate of $2 \mu \mathrm{mol} \cdot \mathrm{min}^{-1} \cdot \mathrm{kg}^{-1}$ during amiloride blockade. The high potassium infusion was discontinued when amiloride was begun to prevent lethal hyperkalemia that would otherwise have resulted from amiloride blockade of potassium secretion. After $1 \mathrm{~h}$ for equilibration, another 30 -min clearance was taken. In a previous study (1), this protocol resulted in stable plasma potassium concentration, acid-base status, and net potassium accumulated from the second to the third clearance periods. Renal function measured during this third clearance period represents function in the potassium-loaded state in the absence of distal potassium secretion.

The abdomen was reopened at the end of the third clearance period and one kidney removed, weighed, and flash frozen in liquid nitrogen within 30-45 s of ligation of the hilar vessels. Kidneys were subsequently stored at $-70^{\circ} \mathrm{C}$ until they were dissected and assayed for $\mathrm{Na}, \mathrm{K}-\mathrm{ATP}$ ase activity.

Body fluid analysis. Whole arterial blood $\mathrm{pH}$ and $\mathrm{PCO}_{2}$ were measured immediately after sampling with a Corning 165/2 pH blood gas analyzer (Ciba Corning Diagnostics Corp., Medfield, MA). This analyzer calculates base excess from the formula described by Siggard-Anderson. Potassium concentrations in the infused solutions, plasma, and urine were determined by flame photometry (Instrumental Laboratories, Lexington, MA; model 443). Plasma and urine osmolality were measured with a Wescor
5100C Vapor Pressure Osmometer (Wescor Inc., Logan, UT). Tritium activity of plasma and urine samples was measured by liquid scintillation counting (Beckman, Irvine, CA; model LS2800) in Scinti Verse I (Fisher Scientific Co., Pittsburgh, PA).

Clearance calculations. GFR was equated with inulin clearance and expressed in $\mathrm{mL} \cdot \mathrm{min}^{-1} \cdot \mathrm{kg}$ body $\mathrm{wt}^{-1}$. Potassium excretion during the 150 -min high potassium infusion was expressed as a fraction of the infused load. Potassium excretion during each of the three clearance periods was expressed in $\mu \mathrm{mol} \cdot \mathrm{min}^{-1} \cdot \mathrm{kg}$ body $\mathrm{wt}^{-1}$. Amiloride-sensitive potassium secretion in the potassium-loaded state was estimated as the difference between urinary potassium excretion during the last $30 \mathrm{~min}$ of $\mathrm{KCl}$ loading (clearance period 2) and potassium excretion during amiloride blockade after $\mathrm{KCl}$ loading (clearance period 3 ).

The TFK at the end of the potassium secretory nephron segments was calculated for each of the three clearance periods as the urine potassium concentration divided by the urine to plasma osmolality ratio $(11,12)$. The TTKG at the same tubular site was calculated as the TFK divided by the plasma potassium concentration at the midpoint of the respective clearance period.

$\mathrm{Na}, \mathrm{K}$-ATPase analysis. Approximately $100-\mathrm{mg}$ samples of cortex and outer medulla were dissected in iced saline from partially thawed transverse sections of kidney and homogenized separately in iced sucrose buffer. Homogenates were then flashfrozen in liquid nitrogen and thawed in ice, and aliquots were taken for Na,K-ATPase and DNA analysis.

$\mathrm{Na}, \mathrm{K}$-ATPase activity was determined under $\mathrm{V}_{\max }$ conditions in duplicate samples from the ouabain-sensitive hydrolysis rate of ${ }^{32} \mathrm{P}-\gamma$-ATP to inorganic ${ }^{32} \mathrm{P}$, as previously described (7). Na,KATPase activity measured under these conditions is proportional to the number of catalytically active enzyme units (13). The DNA content of tissue homogenates was determined spectrophometrically after perchloric acid extraction and reaction with diphenylamine $(14,15)$. Na,K-ATPase activity was expressed as $\mathrm{nmol}$ of ${ }^{32} \mathrm{P}-\gamma$-ATP hydrolyzed per $\mathrm{h}$ per $\mu \mathrm{g}$ DNA and, thus, was proportional to $\mathrm{V}_{\max }$ enzyme activity per cell.

Data analysis. Data are presented as means and SEM. A $p$ value of less than or equal to 0.05 was considered significant. Statistical comparisons of single measures data between agematched control and potassium-supplemented littermate pairs were made using the paired $t$ test when these data were normally distributed. The paired sample Wilcoxon signed rank test was used when they were not. Two-factor analysis of variance with repeated measures of one factor [between-within design (16)] was used to make comparisons between the two groups, among the three clearance periods. If the $F$ ratio for the main effect of clearance period exceeded the critical $F_{0.95}$, then differences among pooled group means were examined using the NewmanKeuls test. If the $F$ ratio for interaction effect exceeded the critical $F_{0.95}$, then differences among cell means were examined using the Newman-Keuls test.

\section{RESULTS}

Forty-one animals were randomly assigned to the control or potassium-supplemented groups. Two of 20 control and three of $21 \mathrm{KCl}$-supplemented animals did not survive the supplementation period or surgical preparation ( $p=0.52$ by Fisher's exact test). Another seven of the control and eight of the potassiumsupplemented animals became anuric after 30-150 min of high potassium infusion $\left(\chi^{2}=0, p=1.0\right)$. Three controls and two potassium-supplemented animals remained unmatched. Clearance studies were complete, therefore, in eight age-matched, littermate pairs. Renal clearance and biochemical data are presented for these eight pairs.

Potassium supplementation. Body weight and growth were not different between the groups at the start of, during, or at the end of the week-long supplemented period (Table 1). Baseline renal clearance data are presented in Table 2 and Figure 1. Baseline data were obtained $14-18 \mathrm{~h}$ after the last gavage, $1 \mathrm{~h}$ after surgical 
Table 1. Body weight and growth during supplementation period

\begin{tabular}{|c|c|c|c|}
\hline & Control* & $\begin{array}{l}\text { Potassium- } \\
\text { supplemented* }\end{array}$ & $p \dagger$ \\
\hline Initial wt (kg)‡ & $0.731(0.064)$ & $0.726(0.071)$ & 0.92 \\
\hline $\begin{array}{l}\text { Age at acute potassium } \\
\text { loading }(d)\end{array}$ & $20(2)$ & $20(2)$ & 0.52 \\
\hline $\begin{array}{l}\text { Body wt at acute potassium } \\
\text { loading }(\mathrm{kg})\end{array}$ & $0.992(0.102)$ & $0.990(0.093)$ & 0.97 \\
\hline
\end{tabular}

* Mean (SEM).

$\uparrow$ Paired $t$ test.

$\ddagger$ Body wt at the beginning of the supplementation period.

Table 2. Baseline renal clearance data*

\begin{tabular}{|c|c|c|c|}
\hline & Control† & $\begin{array}{c}\text { Potassium- } \\
\text { supplemented } \dagger\end{array}$ & $p$ \\
\hline Urine flow rate $\left(\mu \mathrm{L} \cdot \min ^{-1} \cdot \mathrm{kg}^{-1}\right)$ & $44(10)$ & $25(4)$ & $0.04 \ddagger$ \\
\hline Urine osmolality (mosmol/L) & $744(54)$ & $813(81)$ & $0.44 \S$ \\
\hline Plasma osmolality (mosmol/L) & $295(4)$ & $293(3)$ & $0.26 \S$ \\
\hline $\begin{array}{l}\text { Urine osmolality:plasma osmo- } \\
\text { lality }\end{array}$ & $2.53(0.21)$ & $2.78(0.28)$ & $0.41 \S$ \\
\hline GFR $\left(\mathrm{mL} \cdot \mathrm{min}^{-1} \cdot \mathrm{kg}^{-1}\right)$ & $3.2(0.4)$ & $2.9(0.6)$ & $0.50 \S$ \\
\hline $\mathrm{T}_{\mathrm{H}_{2} \mathrm{O}}^{\mathrm{O}}\left(\mu \mathrm{L} \cdot \mathrm{min}^{-1} \cdot \mathrm{kg}^{-1}\right)$ & $62(10)$ & $44(11)$ & $0.09 \S$ \\
\hline
\end{tabular}

* Fourteen to $18 \mathrm{~h}$ after last gavage, $1 \mathrm{~h}$ after surgical preparation under pentobarbital anesthesia, and just before acute potassium loading. $\dagger$ Mean (SEM).

$\ddagger$ Paired sample Wilcoxon signed rank test.

$\S$ Paired $t$ test.

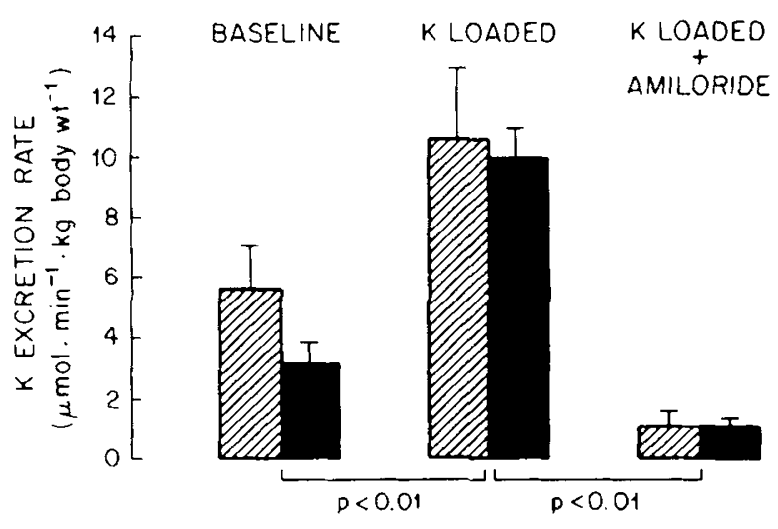

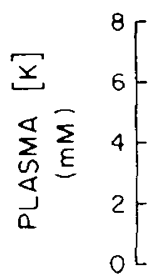
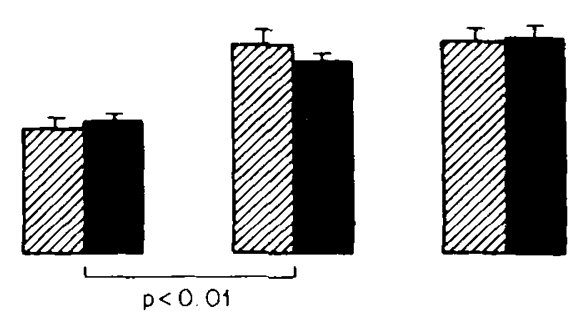

EIDS CONTROL

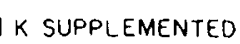

Fig. 1. Urinary potassium excretion rates (top panel) and plasma potassium concentrations (bottom panel) in control and potassiumsupplemented newborn dogs during the first (baseline), second (potassium loaded), and third (potassium loaded with amiloride blockade of distal potassium secretion) clearance periods. Error bars depict SEM. Significance levels were calculated by the Newman-Keuls method after between-within analysis of variance showed a significant effect for clearance period. There was no significant main effect of supplementation or interaction effect on either potassium excretion or plasma potassium concentration. preparation under pentobarbital anesthesia, and just before acute potassium loading. Baseline urine flow rate was significantly greater in controls, although there were no significant differences in GFR, urine or plasma osmolality, or urine osmolality to plasma osmolality ratio (Table 2). $T_{\mathrm{H}_{2} \mathrm{O}}^{\mathrm{O}}$ tended to be lower in the potassium-supplemented animals $(p=0.09)$. Baseline plasma potassium concentrations were similar (Fig. 1, bottom). Although there were no significant experimental or interaction effects on urinary potassium excretion rate by analysis of variance, potassium excretion tended to be less in the potassium-supplemented animals under baseline conditions (Fig. 1, top). The significance level by paired $t$ test was 0.03 . However, there were no significant differences in TFK or in the TTKG in the potassium secretory nephron segments under baseline conditions (Fig. 2).

Potassium loading. Control animals excreted $46 \pm 8 \%$ and potassium-supplemented animals excreted $39 \pm 4 \%$ of the acute potassium load during the 150 -min infusion $(p=0.45)$. Renal clearance data during the second clearance period (last $30 \mathrm{~min}$ of potassium loading) are presented in Table 3 and Figure 1. Urine osmolality was lower in control than potassium-supplemented animals $(p=0.01)$, but the differences in urine flow rate and $\mathrm{T}_{\mathrm{H}_{2} \mathrm{O}}^{\mathrm{O}}$ observed under baseline conditions abated. Urinary potassium excretion rates (Fig. 1, top) increased similarly to rates
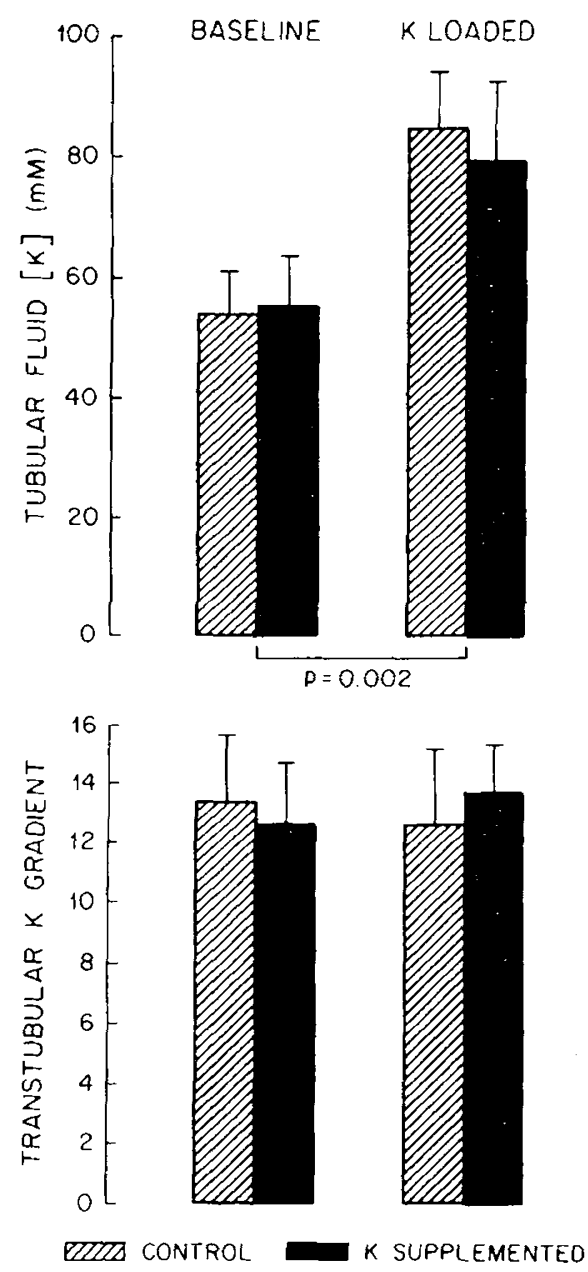

Fig. 2. The apparent tubular fluid potassium concentrations (top) panel) and the transtubular potassium concentration gradients (bottom panel) at the end of the potassium secretory nephron segment(s) for control and potassium supplemented newborn dogs at baseline and at the end of potassium loading. Error bars depict SEM. The significance level indicated was determined by between-within analysis of variance. There was no significant main effect of supplementation on TFK or TTKG, no main effect of clearance period on TTKG, and no interaction effect on TFK or TTKG. 
Table 3. Renal clearance data during acute potassium loading (second clearance period)

\begin{tabular}{lccc}
\hline & \multicolumn{3}{c}{$\begin{array}{c}\text { Potassium- } \\
\text { supplemented* }\end{array}$} \\
\hline Urine flow rate $\left(\mu \mathrm{L} \cdot \mathrm{min}^{-1} \cdot \mathrm{kg}^{-1}\right)$ & $54(10)$ & $51(5)$ & 0.86 \\
Urine osmolality $(\mathrm{mosmol} / \mathrm{L})$ & $675(125)$ & $796(58)$ & 0.01 \\
Plasma osmolality $(\mathrm{mosmol} / \mathrm{L})$ & $302(9)$ & $296(3)$ & 0.32 \\
Urine osmolality:plasma osmo- & $2.25(0.17)$ & $2.50(0.17)$ & 0.22 \\
$\quad$ lality & & & \\
GFR $\left(\mathrm{mL} \cdot \mathrm{min}^{-1} \cdot \mathrm{kg}^{-1}\right)$ & $2.9(0.5)$ & $3.4(0.4)$ & 0.43 \\
$\mathrm{~T}^{\mathrm{c}} \mathrm{H}_{2} \mathrm{O}\left(\mu \mathrm{L} \cdot \mathrm{min}^{-1} \cdot \mathrm{kg}^{-1}\right)$ & $70(15)$ & $84(9)$ & 0.48 \\
\hline
\end{tabular}

$*$ Mean (SEM).

$\dagger$ Paired $t$ test.

3- to 4-fold greater than baseline ( $p<0.01$ by Newman-Keuls). There was no difference between the groups in the absolute increase in potassium excretion from the first (baseline) to the second (potassium-loaded) clearance period.

Plasma potassium concentration (Fig. 1, bottom) increased significantly, but similarly, in the control and potassium-supplemented groups over the course of the experiment from approximately 4.3 to $6.6 \mathrm{mM}$ ( $p<0.01$ by Newman-Keuls).

Figure 2 shows the calculated TFK and TTKG at the end of the potassium secretory nephron segment(s) under baseline (clearance period 1) and potassium-loaded (clearance period 2) conditions. TFK increased significantly, but similarly, in control and potassium-supplemented animals from 55 to $84 \mathrm{mM}$ $\left(F_{[1,14]}=13.7, p=0.002\right)$ during the high potassium infusion. TTKG remained unchanged at approximately 13 .

Potassium loading: amiloride blockade. As shown in the top panel of Figure 1, blockade of amiloride-sensitive potassium secretion produced a marked, but similar, fall in potassium excretion in control and potassium-supplemented animals $(p<$ 0.01 , clearance period 2 versus clearance period 3, by NewmanKeuls). Amiloride inhibited $90 \pm 2 \%$ of potassium excretion in controls and $89 \pm 2 \%$ in potassium-supplemented animals in the potassium-loaded state ( $p=0.63$ by paired $t$ test).

Plasma potassium concentration (Fig. 1, bottom panel) tended to increase in both groups from the second to the third clearance periods from approximately 6.6 to $7 \mathrm{mM}$ ( $p>0.05$ NewmanKeuls). However, there were no significant differences in net potassium accumulated (calculated as the difference in cumulative potassium infused and cumulative potassium excreted) by the midpoints of the second and third clearance periods in either group. Controls accumulated $1.5 \pm 0.2 \mathrm{mmol} / \mathrm{kg}$ body wt by the second and $1.5 \pm 0.3 \mathrm{mmol} / \mathrm{kg}$ by the third clearance period. Potassium-supplemented animals accumulated $1.7 \pm 0.1 \mathrm{mmol} /$ $\mathrm{kg}$ by the second and $1.6 \pm 0.2 \mathrm{mmol} / \mathrm{kg}$ by the third clearance period. Arterial pH remained unchanged in both groups from the second to the third clearance periods. Amiloride-sensitive potassium secretion in the potassium-loaded state was $9.6 \pm 1.8$ $\mu \mathrm{mol} \cdot \mathrm{min}^{-1} \cdot \mathrm{kg}$ body $\mathrm{wt}^{-1}$ in control animals and $8.9 \pm 0.8$ $\mu \mathrm{mol} \cdot \mathrm{min}^{-1} \cdot \mathrm{kg}$ body $\mathrm{wt}^{-1}$ in potassium-supplemented animals, $p=0.77$ by paired $t$ test.

TFK during amiloride blockade in the potassium-loaded state (clearance period 3) are shown for each group along with the corresponding TTKG in Figure 3. Neither TFK nor TTKG in the potassium-loaded state with amiloride blockade differed between the groups. Moreover, TTKG was not different from 1 for either group.

Na,K-ATPase activity. Cortical Na,K-ATPase activities under $\mathrm{V}_{\max }$ conditions are shown for each of the eight age-matched, littermate controls in Figure 4. Enzyme activity was greater in the potassium-supplemented member of six of the eight pairs after 1 wk of supplementation. Mean Na,K-ATPase activities were $198 \pm 44$ and $279 \pm 58 \mathrm{nmol}$ inorganic $\mathrm{P}$ liberated $\cdot \mathrm{h}^{-1} \cdot \mu \mathrm{g}$ DNA $^{-1}$ in control and potassium-supplemented newborn dogs, respectively ( $p=0.05$ by paired $t$ test). The mean increase in

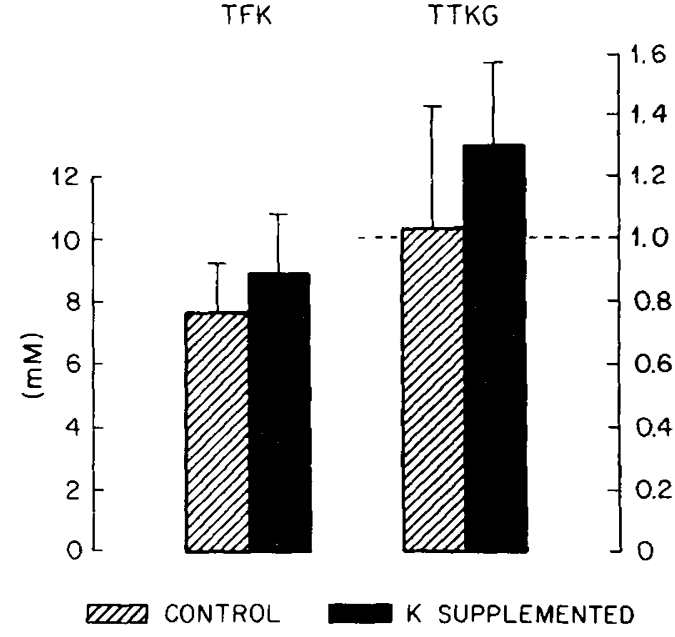

Fig. 3. The apparent tubular fluid potassium concentrations and the transtubular potassium concentration gradients for control and potassium-supplemented newborn dogs in the potassium-loaded state with amiloride blockade of distal potassium secretion. There are estimates of TFK and TTKG in the absence of an electrical gradient across the luminal membrane of potassium secretory cells. Error bars represent SEM.

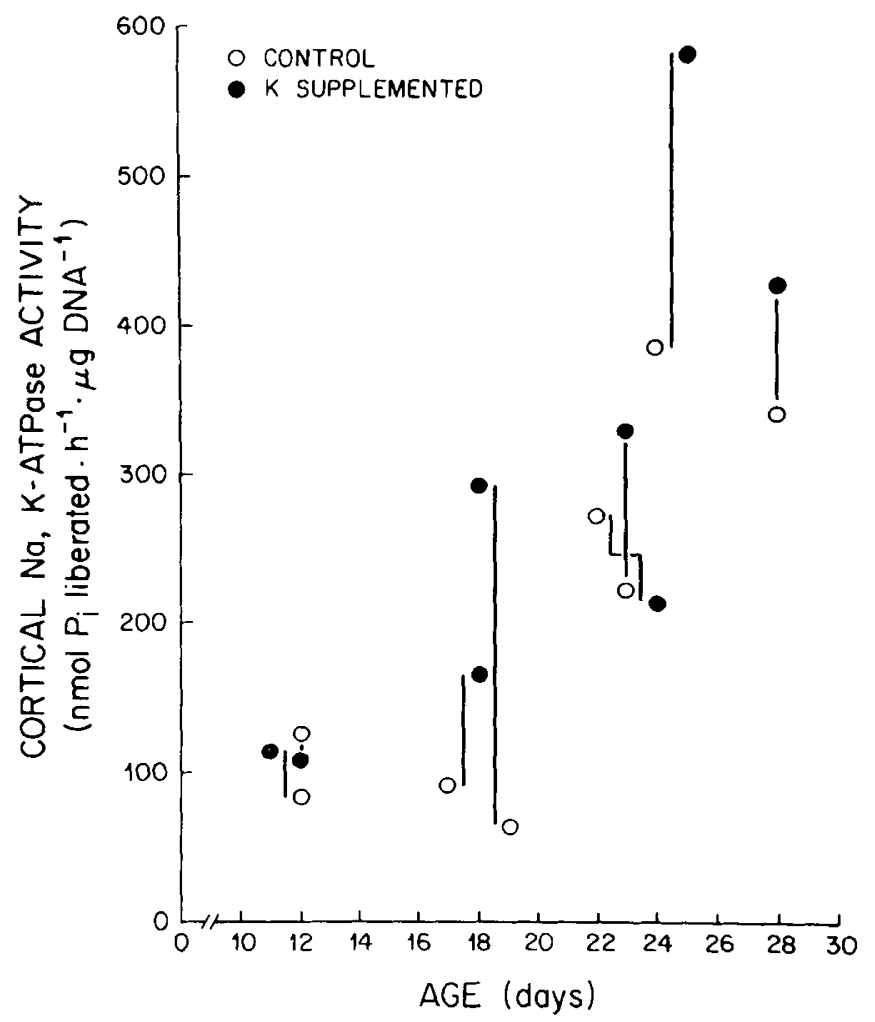

Fig. 4. Renal cortical homogenate $\mathrm{Na}, \mathrm{K}$-ATPase activity under $\mathrm{V}_{\max }$ conditions for control and potassium-supplemented newborn dogs. Vertical lines denote age-matched, littermate pairs. Each animal is depicted at its age at the time of acute potassium loading and removal of kidney for Na,K-ATPase assay. Paired $t=2.36$ with $7 d f, p=0.05$.

$\mathrm{Na}, \mathrm{K}-\mathrm{ATPase}$ activity after 1 wk of potassium supplementation was $70 \%$.

Outer medullary activity under $\mathrm{V}_{\max }$ conditions was $166 \pm 16$ and $155 \pm 32 \mathrm{nmol}$ inorganic $\mathrm{P}$ liberated $\cdot \mathrm{h}^{-1} \cdot \mu \mathrm{g} \mathrm{DNA}^{-1}$ in control and potassium-supplemented dogs, respectively $(p=0.74$ by paired $t$ test). 


\section{DISCUSSION}

Chronic potassium supplementation of newborn dogs for $1 \mathrm{wk}$ resulted in an average increase in cortical Na,K-ATPase activity, under $\mathrm{V}_{\text {max }}$ conditions, of $70 \%$ over that in controls. However, this increase in pump abundance did not blunt the development of hyperkalemia during acute potassium loading and did not enhance urinary potassium excretion or increase the TTKG in potassium secretory nephron segment(s) under baseline conditions or during acute potassium loading. Moreover, there was no difference in amiloride-sensitive potassium secretion between control and potassium-supplemented animals. Even if the two littermate pairs in which Na,K-ATPase activity in the control exceeded that in the potassium-supplemented animal are excluded from the analysis, no effect of chronic supplementation or enhanced $\mathrm{Na}, \mathrm{K}$-ATPase activity could be demonstrated in response to acute potassium loading. These results substantiate those of our previous study and support a lack of effect of increased pump abundance on amiloride-sensitive potassium secretion as well as on urinary potassium excretion in the newborn dog. Moreover, they eliminate water loading in controls as a confounding variable in our previous study.

These results are best interpreted in light of what is known about renal potassium handling in the adult. Potassium transport in late distal and collecting tubules largely determines urinary potassium excretion in the adult (17). Transcellular potassium secretion and sodium reabsorption are coupled and directly linked to the active, electrogenic exchange of sodium and potassium across the basolateral membranes of connecting tubule cells and principal cells in these nephron segments (18-21). Basolateral membrane Na,K-ATPase generates the electrochemical gradients that permit the passive exchange of sodium and potassium across the luminal membranes. Factors that alter potassium secretion may do so by affecting basolateral membrane $\mathrm{Na}-\mathrm{K}$ pump abundance or turnover rate or luminal membrane $\mathrm{Na}-\mathrm{K}$ flux $(22,23)$. Dietary potassium supplementation enhances distal nephron potassium secretion and urinary potassium excretion under baseline conditions $(9,21,24-31)$ as well as during potassium loading $(9,10,27-31)$. This enhanced secretory capacity is at first the result of an increase in $\mathrm{Na}-\mathrm{K}$ pump turnover rate without a change in pump number $(23,28)$. With continued supplementation, basolateral pump number increases and pump turnover rate returns to baseline, so that the enhanced potassium secretory capacity is maintained by increased pump abundance alone $(28,32)$. Electron microprobe analysis of intracellular sodium and potassium activities in connecting tubule and principal cells from chronically potassium-supplemented rats has shown that enhanced sodium reabsorption and potassium secretion in these nephron segments is associated with decreases in cell sodium activity without marked increases in cell potassium activity (24). Because increased $\mathrm{Na}, \mathrm{K}$-ATPase activity results in increased sodium extrusion and potassium uptake at the basolateral membrane, these findings imply that luminal membrane potassium, and perhaps sodium, conductance or passive driving forces must increase with chronic potassium loading $(24,33)$. It is not known which, if any, of the factors that affect the ion conductance or passive driving forces across the luminal membranes of connecting tubule and principal cells is responsible for this increase in apical sodium and/or potassium flux with chronic potassium loading.

The findings of this and our previous study of the effects of chronic potassium supplementation in newborn dogs are thus different from what has been shown in the adult. Therefore, this discrepancy might be explained by consideration of what is known about similarities and differences in renal potassium handling between the newborn and adult.

The present and previous studies of the effect of amiloride on urinary potassium excretion $(1,34)$ confirm that amiloride almost completely inhibits urinary potassium excretion in both the newborn and adult dog. This indicates that, in the newborn, urinary potassium excretion is largely the result of amiloridesensitive potassium secretion and that the cellular mechanisms of potassium excretion are similar to those in the adult.

The validity of the former conclusion depends upon the reliability of the method used to determine amiloride-sensitive potassium secretion. This calculation assumes that the effect of amiloride, at the dose used, is limited to the potassium secretory nephron segment and that the decrement in potassium excretion with amiloride infusion is the result of pharmacologic blockade and not the discontinuation of the high potassium infusion. The data supporting these assumptions have been previously reviewed $(1,34)$ and support the assertion that this method provides a reasonable estimate of amiloride-sensitive potassium secretion. In addition, the TTKG of approximately unity during amiloride blockade in both control and potassium-supplemented groups indicates that amiloride blocks essentially all active potassium secretion in the potassium-loaded state $(11,12)$.

The conclusion that the cellular mechanism of potassium secretion is similar in the newborn and adult is based upon the mechanism of action of amiloride at the cellular level. Amiloride selectively blocks the luminal membrane sodium conductance channel in potassium secretory cells $(35,36)$. Thus, the nearcomplete inhibition of potassium secretion by amiloride in the newborn implies that potassium efflux from potassium secretory cells is coupled to transluminal membrane sodium influx.

We have not directly confirmed that the increase in renal cortical Na,K-ATPase associated with chronic potassium loading occurs in the potassium secretory nephron segments. However, chronic potassium supplementation has not been reported to increase $\mathrm{Na}, \mathrm{K}-\mathrm{ATPase}$ activity in any other cortical nephron segments in adult animals $(18,20,25,26)$. It is possible that the magnitude of the increase in Na,K-ATPase activity with chronic potassium supplementation of the newborn dog is not sufficient to produce a detectable increase in potassium secretion. This seems unlikely, however, because in chronically potassium-supplemented adult animals the percentage of increase in urinary potassium excretion is greater than or equal to the associated percentage of increase in segmental Na,K-ATPase activity (25, 29). Moreover, if chronic potassium supplementation of the newborn dog increases $\mathrm{Na}, \mathrm{K}-\mathrm{ATPase}$ activity in potassium secretory nephron segments only (and not in the proximal convoluted tubule, for example) then whole cortex enzyme activity would underestimate the percentage of increase in these nephron segments $(25,37)$.

We conclude, therefore, that in the newborn 1 ) potassium secretory/excretory capacity is closely linked to Na,K-ATPase activity in amiloride-sensitive potassium secretory nephron segments; 2) dietary potassium supplementation increases cortical $\mathrm{V}_{\max } \mathrm{Na}$, K-ATPase activity, most likely in potassium secretory nephron segments; 3) the magnitude of the increase in $V_{\max }$ $\mathrm{Na}, \mathrm{K}-\mathrm{ATP}$ ase activity would be expected to be physiologically significant by adult standards; and 4) this increase in $\mathrm{V}_{\max } \mathrm{Na}, \mathrm{K}$ ATPase does not enhance potassium secretory capacity. These paradoxical conclusions can be reconciled by considering the relationship between $\mathrm{V}_{\max } \mathrm{Na}, \mathrm{K}-\mathrm{ATPa} e$ activity in vitro and pump activity in vivo.

$\mathrm{V}_{\max }$ activity represents the maximum hydrolytic activity of all available enzyme units (22) and is thus proportional to pump abundance. In the intact cell, Na,K-ATPase activity is a function of both pump abundance and catalytic turnover rate of individual pump units (28). Under physiologic conditions, intracellular sodium activity or the intracellular $\mathrm{Na} \mathrm{K}$ ratio regulates enzyme turnover rate. ${ }^{\prime}$ An increase in intracellular sodium activity or

'Strictly speaking, the catalytic turnover rate is a function of the kinetic properties of the enzyme, as well as of intracellular sodium activity or the Na:K ratio. However, chronic dietary potassium supplementation has little or no effect on the kinetic properties of the stimulated enzyme in the adult animal (32). To evaluate this in the newborn dog, kinetic curves for sodium and potassium were generated in cortical and outer medullary tissue samples from three control and two potassium-supplemented animals. There were no differences in the $K_{1 / 2}$ for either substrate between experimental groups. The apparent $K_{1 / 2}$ for sodium in cortex was $20.9 \pm 1.1 \mathrm{mM}$ in supplemented and $21.5 \pm 1.3 \mathrm{mM}$ in control animals. The $\mathrm{K}_{1 / 2}$ for sodium in outer medulla was $17.5 \pm 2.2 \mathrm{mM}$ in supplemented and $18.3 \pm 2.8 \mathrm{mM}$ in control animals. The $\mathrm{K}_{1 / \mathrm{f}}$ for potassium in cortex was $2.3 \pm 0.09$ and $2.2 \pm 0.07 \mathrm{mM}$ in potassium-supplemented and control animals, respectively. These differences were not statistically significant. These data, therefore, confirm that chronic dietary potassium supplementation does not alter the kinetic properties of the enzyme in the immature kidney. 
$\mathrm{Na}: \mathrm{K}$ ratio stimulates pump turnover; a decrease inhibits pump turnover. Under baseline conditions, pump turnover rate is limited to less than $10 \%$ of maximum in connecting tubule and principal cells and is very sensitive to small changes in cytoplasmic sodium activity or Na:K ratio $(24,38,39)$.

Therefore, in vitro $\mathrm{V}_{\max } \mathrm{Na}, \mathrm{K}-\mathrm{ATP}$ ase activity (pump abundance) does not strictly regulate potassium secretion, even in the adult. Actual in vivo Na,K-ATPase activity in potassium-secreting cells is the critical factor (28). As noted above, Na,K-ATPase activity in vivo is a function of pump abundance and pump turnover rate. Therefore, we propose that restriction of pump turnover rate is the explanation for the failure of the increase in pump abundance to produce an increase in potassium secretory capacity in the newborn. This restricted Na-K pump turnover rate might well be the result of failure of the luminal membrane sodium and/or potassium conductances, or the passive transmembrane driving forces, to increase. If one or the other of these failed to increase with chronic potassium loading along with basolateral membrane pump abundance in connecting tubule and principal cells [as it apparently does in the adult (40)], then the resulting increase in $\mathrm{Na}, \mathrm{K}$-ATPase activity would lower cytoplasmic sodium activity and/or raise cytoplasmic potassium activity. Consequently, lower $\mathrm{Na}: \mathrm{K}$ cytoplasmic ratio would itself restrict pump turnover rate in vivo (39). Thus, in vivo, Na, KATPase activity and potassium secretory capacity might remain unchanged, or even decrease, compared with controls despite an increase in pump abundance. Indeed, the lower baseline urinary potassium excretion rate in the potassium-supplemented animals compared with controls suggests that in vivo Na,K-ATPase activity in the potassium secretory nephron segments may actually have been lower in the former group. This difference in potassium excretion is not likely to be spurious, inasmuch as the rates of urinary potassium excretion were identical in each group to those in our previous study (7). In this regard, the basal urine flow rates in this study suggest a possible explanation for the failure of $\mathrm{Na}-\mathrm{K}$ exchange across luminal membranes to increase. Adult animals invariably increase their urine flow rates after potassium supplementation $(24,25,29-31,41)$. Balance studies have shown this to be the result of increased free water intake $(25,28-30,41)$. Fujii et al. (28) have speculated that this enhanced urine flow facilitates excretion of the chronic potassium load. In the present study, basal urine flow rate was significantly lower in potassium-supplemented animals. Urine flow rates in each group were almost identical in our previous study (7). Although no balance data could be obtained, this difference from the adult is probably the result of the lack of a source of free water in the suckling, potassium-supplemented newborn dogs. It also suggests that chronic high potassium intake per se decreases urine output if free water intake is not increased. Although urine flow rate does not necessarily parallel distal tubule fluid flow rate, lower $\mathrm{T}^{\mathrm{c}}{ }_{\mathrm{H}_{2} \mathrm{O}}$ without a lower urine to plasma osmolality ratio in the potassium-supplemented versus the control group indicates that the tubular fluid flow rate out of the proximal tubule was lower in the potassium-supplemented group under baseline conditions. A lower luminal sodium concentration and perhaps fluid flow rate into the distal tubule from the loop of Henle would be expected as a result. These factors depress potassium secretion in the late distal and cortical collecting tubules $(3,42)$. We speculate, therefore, that in potassiumsupplemented animals potassium excretion may be lower under baseline conditions despite increased $\mathrm{Na}, \mathrm{K}$-ATPase pump abundance because distal fluid flow rate and sodium concentration are lower than in controls. The differences in potassium excretion rates, in urine flow rate, and $\mathrm{T}^{\mathrm{c}}{ }_{\mathrm{H}_{2} \mathrm{O}}$ did not persist during acute potassium loading. Thus, differences in distal fluid flow rate and sodium concentration and Na-K pump turnover rate may abate somewhat during acute potassium loading. However, the turnover rate of the greater number of pumps in the potassiumsupplemented group may remain lower than that of controls, so that potassium secretion is similar.
The possibility cannot be excluded that the failure to demonstrate an increased potassium secretory capacity after chronic potassium loading was the result of failure of the latter to produce an increase in outer medullary Na,K-ATPase activity in this experimental model. Heterogeneity of responsiveness to chronic potassium loading appears to exist in different collecting tubule segments $(25-27,41)$. There is one study that suggests that an increase in outer medullary Na,K-ATPase is necessary for potassium adaptation in the rat. This does not appear to be the case in the rabbit (26). No information is available in the dog.

In summary, chronic potassium loading for $1 \mathrm{wk}$ resulted in a $70 \%$ increase in cortical homogenate $V_{\max } \mathrm{Na}, \mathrm{K}$-ATPase activity in the newborn dogs. Assuming this process to be analogous to that in the adult, this increase is indicative of an increase in basolateral membrane pump abundance in connecting tubule and/or principle cells of the potassium secretory nephron segments and would be expected to increase potassium secretory capacity. However, this increase in pump abundance did not increase the calculated TFK or TTKG in the potassium secretory nephron segments, amiloride-sensitive potassium secretion, or urinary potassium excretion. These results are inconsistent with the hypothesis that the lower potassium secretory capacity of the newborn compared with that of the adult is the result of lower pump abundance in the potassium secretory nephron segments. We propose that both the lower potassium secretory capacity of the newborn during acute potassium loading and the failure of chronic potassium supplementation to enhance secretory capacity are the result of limitation of Na,K-ATPase turnover rate in vivo. We speculate that in the latter case, this restricted turnover rate may be the result of lower passive driving forces for the Na$\mathrm{K}$ exchange across the luminal membrane as a consequence of lower sodium concentration in and/or water delivery to the potassium secretory nephron segments.

Acknowledgments. The authors thank Dr. Leonard I. Kleinman for his valuable comments and criticisms during the preparation of this manuscript, Katherine Markarian for her excellent technical assistance and Fran Vatore for her expert assistance with the manuscript preparation. We also thank Dr. Clement A. Stone of Merck Sharp \& Dohme Research Laboratories for supplying the amiloride used in this study.

\section{REFERENCES}

1. Lorenz JM, Kleinman LI, Disney TA 1986 Renal response of newborn dog to potassium loading. Am J Physiol 251:F513-F519

2. Koeppen BM, Biagi BA, Giebisch GH 1983 Intracellular microelectrode characterization of the rabbit cortical collecting duct. Am J Physiol 244:F35F47

3. Stokes JB 1981 Potassium secretion by cortical collecting tubule: relation to sodium absorption, luminal sodium concentration, and transepithelial voltage. Am J Physiol 241:F395-F402

4. Holthofer H 1987 Ontogeny of cell type-specific enzyme reactivities in kidney collecting ducts. Pediatr Res 22:504-508

5. Minuth WW, Gross P, Gilbert P, Kashgarian M 1987 Expression of the $\alpha$ subunit of $\mathrm{Na} / \mathrm{K}-\mathrm{ATPase}$ in renal collecting duct epithelium during development. Kidney Int 31:1104-1112

6. Schmidt U, Horster M 1977 Na-K-activated ATPase: activity maturation in rabbit nephron segments dissected in vitro. Am J Physiol 233:F55-F60

7. Lorenz JM, Manuli MA, Browne LE 1990 Chronic potassium supplementation of newborn dogs increases cortical Na,K-ATPase but not urinary potassium excretion. J Dev Physiol 13:181-188

8. Field MJ, Stanton BA, Giebisch GH 1984 Differential acute effects of aldosterone, dexamethasone, and hyperkalemia on distal tubular potassium secretion in the rat kidney. J Clin Invest 74:1792-1802

9. Wright FS, Strieder N, Fowler NB, Giebisch G 1971 Potassium secretion by distal tubule after potassium adaptation. Am J Physiol 221:437-448

10. Berliner RW, Kennedy Jr TJ, Hilton JG 1950 Renal mechanisms for excretion of potassium. Am J Physiol 162:348-367

11. West ML, Bendz O, Chen CB, Singer GG, Richardson RMA, Sonnenberg H, Halperin ML 1986 Development of a test to evaluate the transtubular potassium concentration gradient in the cortical collecting duct in vivo. Miner Electrolyte Metab 12:226-233

12. West ML, Sonnenberg H, Veress A, Halperin ML 1987 The relationship between the plasma potassium concentration and renal potassium excretion in the adrenalectomized rat. Clin Sci 72:577-583 
13. Segel IH 1986 Biochemical Calculations, 2nd Ed. John Wiley \& Sons, New York, p 242

14. Burton K 1956 A study of the conditions and mechanism of the diphenylamine reaction for the colorimetric estimation of deoxyribonucleic acid. Biochem J 62:315-323

15. Monroe HN, Fleck A 1966 Recent developments in the measurement of nucleic acid in biological material. Analyst 91:78-88

16. Winer BJ 1971 Statistical Principles in Experimental Design. 2nd Ed. McGraw Hill, New York

17. Malnic G, Klose RM, Giebisch G 1964 Micropuncture study of renal potassium excretion in the rat. Am J Physiol 206:674-686

18. Kaissling B, Le Hir M 1982 Distal tubular segments of the rabbit kidney after adaptation to altered Na- and K-intake. I. Structural changes. Cell Tissue Res 224:469-492

19. Kashgarian M, Ardito T, Hirsch DJ, Hayslett JP 1987 Response of collecting tubule cells to aldosterone and potassium loading. Am J Physiol 253:F8F14

20. LeHir M, Kaissling B, Dubach UC 1982 Distal tubular segments of the rabbit kidney after adaptation to altered $\mathrm{Na}$ - and K-intake. II. Changes in Na-K ATPase activity. Cell Tissue Res 224:493-504

21. Stanton BA, Biemesderfer D, Wade JB, Giebisch G 1981 Structural and functional study of the rat distal nephron: effects of potassium adaptation and depletion. Kidney Int 19:36-48

22. Field MJ, Giebisch G 1989 Mechanisms of segmental potassium reabsorption and secretion. In: Seldin DW, Giebisch G (eds) The Regulation of Potassium Balance. Raven Press Ltd, New York

23. Fujii Y, Katz AI 1989 Direct $\mathrm{Na}^{+}-\mathrm{K}^{+}$pump stimulation by $\mathrm{K}^{+}$in cortical collecting tubules: a mechanism for early renal $\mathrm{K}^{+}$adaptation. Am J Physio 257:F595-F60

24. Beck F-X, Dorge A, Rick R, Schramm M, Thurau K 1987 Effect of potassium adaptation on the distribution of potassium, sodium and chloride across the apical membrane of renal tubular cells. Pflugers Arch 409:477-485

25. Doucet A, Katz AI 1980 Renal potassium adaptation: Na-K-ATPase activity along the nephron after chronic potassium loading. Am J Physiol 238:F380 F386

26. Garg LC, Narang N 1985 Renal adaptation to potassium in the adrenalectomized rabbit. Role of distal tubule sodium-potassium adenosine triphosphatase. J Clin Invest 76:1065-1070
27. Finkelstein FO, Hayslett JP 1975 Role of medullary Na-K-ATPase in rena potassium adaptation. Am J Physiol 229:524-528

28. Fujii Y, Mujais SK, Katz AI 1989 Renal potassium adaptation: role of the $\mathrm{NA}^{+}-\mathrm{K}^{+}$pump in rat cortical collecting tubules. Am J Physiol 256:F279 F284

29. Mujais SK 1988 Renal memory after potassium adaptation: role of $\mathrm{Na}^{+}-\mathrm{K}^{+}$ ATPase. Am J Physiol 254:F845-F850

30. Schnermann J, Steipe B, Briggs JP 1987 In situ studies of distal convoluted tubule in the rat. II. K secretion. Am J Physiol 252:F970-F976

31. Schon DA, Backman KA, Hayslett JP 1981 Role of the medullary collecting duct in potassium excretion in potassium-adapted animals. Kidney In 20:655-662

32. Rodriguez HJ, Hogan WC, Hellman RN, Klahr S 1980 Mechanism of activation of renal $\mathrm{Na}^{+}-\mathrm{K}^{+}$-ATPase in the rat: effects of potassium loading. Am J Physiol 238:F315-F323

33. Sansom SC, Agulian S, Muto S, Illig V, Giebisch G 1989 K activity of CCD principal cells from normal and DOCA-treated rabbits. Am $\mathfrak{J}$ Physiol 256:F136-F142

34. Banks RO, Kleinman LI 1978 Effect of amiloride on the renal response to saline expansion in newborn dogs. J Physiol (Lond) $275 \cdot 521-534$

35. Benos DJ 1982 Amiloride: a molecular probe of sodium transport in tissues and cells. Am J Physiol 242:C131-C145

36. O'Neil RG, Boulpaep EL 1979 Effect of amiloride on the apical cell membrane cation channels of a sodium-absorbing, potassium-secreting renal epithelium. J Membr Biol 50:365-387

37. Garg LC, Knepper MA, Burg MB 1981 Mineralocorticoid effects on Na-KATPase in individual nephron segments. Am J Physiol 240:F536-F544

38. Blot-Chabaud M, Jaisser F, Gingold M, Bonvalet JP, Farman N $1988 \mathrm{Na}^{+}$ $\mathrm{K}^{+}$-ATPase-dependent sodium flux in cortical collecting tubule. Am J Physiol 255:F605-F613

39. Jorgenson PL 1986 Structure, function and regulation of $\mathrm{Na}, \mathrm{K}-\mathrm{ATP}$ ase in the kidney. Kidney Int 29:10-20

40. Muto S, Sansom S, Giebisch G 1988 Effects of a high potassium diet on electrical properties of cortical collecting ducts from adrenalectomized rab bits. J Clin Invest 81:376-380

41. Mujais SK, Chekal MA, Hayslett JP, Katz Al 1986 Regulation of renal $\mathrm{Na}^{+}$ $\mathrm{K}^{+}$-ATPase in the rat: role of increased potassium transport. Am $\mathbf{J}$ Physiol 251:F199-F207

42. Good DW, Wright FS 1979 Luminal influences on potassium secretion sodium concentration and fluid flow rate. Am J Physiol 236:F192-F205 